\title{
Purchase Order Analysis Imported Goods in PT. XYZ
}

\author{
Darno $^{1}$, Khadijah Binti MD Ariffin ${ }^{2}$, Hariyati $^{3}$, Dewi Agustya Ningrum ${ }^{4}$, Siti Mahmudah $^{5}$ \\ \{darno@dosen.umaha.ac.id ${ }^{1}$, hadija@uthm.edu.my ${ }^{2}$, hariyati@unesa.ac.id ${ }^{3}$, \\ dewi_agustyaningrum@dosen.umaha.ac.id ${ }^{4}$, siti_mahmudah@dosen.umaha.ac.id ${ }^{5}$ \} \\ Universitas Maarif Hasyim Latif, Indonesia ${ }^{1,4,5}$, Universiti Tun Hussein Onn Malaysia, Malaysia ${ }^{2}$, \\ Universitas Negeri Surabaya, Indonesia ${ }^{3}$
}

\begin{abstract}
The purpose of this research is to find out the Purchase Order / PO process and to know the obstacles in the PO process. This research was carried out based on descriptive qualitative methods. Analysis is carried out on the system in the company and compared with the input theory. Problems faced by companies in the purchase order process (PO) include; sending time, technical payment, technical and location of delivery of goods, unit price of goods and total price. The most common obstacle is the technical time and place of delivery of goods. This incident is caused by the purchasing department not filling in the section or column "condition". This causes the process of purchasing goods or purchase orders to stop or fail. Constraints and obstacles in the PO process can lead to errors in completing the work of each division. Delays and errors that occur in each division outside the tolerance limit will cause difficulties and disrupt the company's operational plan. It is recommended that each writing description in the PO be written clearly and also in detail. This is to clarify every element in the PO in order to avoid misunderstandings with the agreements listed in the PO. To improve procurement quality, it is necessary to have the principle of procurement of goods, namely efficient and effective, transparent and open, competitive prices, and fair and accountable.
\end{abstract}

Keywords: Purchase Order, Imported Goods, Procurement.

\section{Introduction}

Perkembangan perdagangan dalam negeri dan juga antar negara jumlah semakin naik. Perkembangan teknologi informasi serta komunikasi semakin membuat batas anatar negara seakan menjadi tidak ada. Transakasi perdagangan antar negara semakin naik dan ketergantungan masing-masing negara juga semakin meningkat. Transaksi perdagangan melampaui batas negara ini di sebut kegiatan kegiatan export-import. Tidak ada suatu negara yang tertutup tidak melakukan transaksi perdagangan dengan neraga lain, kebutuhan negara akan suatu barang menimbulkan kegiatan perdagangan internasional. Sekarang ini tidak ada negara "autarki" atau tertutup, "suatu negara terisolasi tanpa ada hubungan ekonomi dan keuangan, serta perdagangan internasional atau export-import" (Hamdi Hady, 2001:17).

Dalam suatu perusahaan terdapat banyak pelaku ekonomi, baik itu pemerintahan sendiri maupun pihak swasta. Untuk memenuhi kebutuhannya pihak pemerintah maupun swasta (perusahaan) pasti melakukan pembelian barang (purchasing). Purchasing memilki peranan vital dalam pengelolaan (manajemen) perusahaan. Purchasing bertugas untuk pengadaan kebutuhan barang yang diperlukan oleh perusahaan. Khusus untuk perusahaan dalah untuk 
pencarian, pemesanan dan pembelian bahan baku, alat-alat produksi, peralatan-perlengkapan produksi dan fasilitas-fasilitas lainnya untuk kelancaran proses produksi.

Hambatan-hambatan dalam proses Purchase Order (PO) yang terjadi yaitu ada beberapa pembeli terkadang purchase order (PO) tidak diberikan dalam suatu dokumen tertulis. Hal ini menyebabkan tidak adanya alat pengikat kedua belah pihak baik pembeli (buyer) maupun penjual (seller) untuk melaksanakan hak serta kewajiban masing-masing (Ineke Febriana $\mathrm{H}$; 2009).

Di Jawa Timur terdapat PT. XYZ, perusahaan yang memproduksi jenis Billet, Flat Bar, dan Round Bar Special Steel. Untuk bahan baku diperoleh dari dalam negeri dan sebagian kecil diluar negeri. Untuk pembelian produk di perusahaan tersebut ditangani oleh Departemen Pembelian yang terbagi menjadi 2 divisi yaitu Pembelian Lokal (dalam negeri) dan Pembelian Impor (luar negeri). Pembagian tugas ini supaya tidak terjadi tumpang tindih pekerjaan. Dan juga terkait dengan kapasitas SDM yang ada pada masing-masing bagian purchasing. Hal ini disebabkan oleh pembelian barang yang terjadi dalam negeri dan pembelian barang dari luar negeri memiliki aturan yang beda. Yang membedakan adalah pada saat waktu mendatangkan barang, dimana prosesnya perlu kerja sama dengan exim atau export-import di perusahaan dalam proses pengurusan dokumen untuk impor dalam hal ini ke bea cukai.

Proses bisnis di perusahaan dilakukan dalam bentuk investasi supaya terjadi perputaran uang. Untuk menjalakan proses bisnis, perusahaan harus melakukan proses pengadaan atau pembelian barang. Dalam dunia bisnis disebut dengan procurement atau purchasing. Perusahaan harus menjamin bahwa proses pengadaaan atau pembelian bisa berjalan lancar dan tidak mengganggu proses produksinya. Untuk itu, proses procurement harus di kontrol supaya tidak ada kendala dalam proses internalnya. Salah satu alat (tools) kontrol yang dipakai dalam proses pengadaan barang ini adalah Purchase Order atau PO. Purchase Order pada dasarnya berisi surat perjanjian antara customer (pembeli) dengan vendor (penyedia) bahwa customer akan membeli barang seperti di dokumen dengan ketentuan jumlah dan harga seperti di dokumen. Purchase order ini menjadi pedoman dalam proses pembelian barang antara penyedia dengan pembeli.

Pada prakteknya, Purchase Order (PO) berisi tentang jenis barang, harga harga, jumlah barang, sistem pembayaran dan waktu serta tempat penyerahan barang. Pada praktek dilapangan banyak bagian pembelian atau purchasing di perusahaan yang tidak lengkap mengisi form Purchase Order sehingga penyedia akan kebingungan untuk memenuhi kebutuhan customer dalam melaksanakan PO yang ada. Hal ini akan menyebabkan proses PO akan menjadi bermasalah. Ada beberapa sebab kendala yang menyebabkan PO menjadi bermasalah yaitu terkait harga barang, jumlah barang, waktu dan tempat penyelesaiaan, serta pemenuhan spsesifikasi yang diminta.

Adanya masalah atau kendalan terkait proses pengadaan barang ini, sehingga diperlukan penelitian untuk mengetahui, mempelajari dan memberikan masukkan mengenai proses PO disuatu perusahaan. Proses penelitain ini dilakukan pada PT. XYZ dalam proses pengdaan khususnya barang impor. Dari hal itu penulis akan mengangkat tema itu menjadi pokok permasalahan yang berjudul "ANALISIS PENGENDALIAN PEMBELIAN (PURCHASE ORDER) BARANG IMPOR PADA PT. XYZ”.

\subsection{Rumusan masalah}

Berdasar pada pengamatan yang dilakukan selama proses penelitian di PT. XYZ khusunya di Departemen Purchasing, maka rumusan masalah dalam penelitian ini adalah;

1. Bagaimana proses PO (Purchase Order) khususnya barang impor. 
2. Bagaimana hambatan-hambatan dalam proses PO (Purchase Order) barang impor.

\subsection{Tujuan}

Tujuan penelitian ini adalah;

1. Mengetahui proses PO (Purchase Order) impor.

2. Mengetahui hambatan-hambatan dalam proses PO (Purchase Order).

3. Memberikan alternatif solusi untuk perbaikan proses PO khususnya barang import.

\subsection{Metode penelitian}

Penelitian ini dilaksanakan dengan menggunakan metode kualitatif deskriptif. Dimana dilakukana analisa terhadap sistem yang ada diperusahaan dan dibandingan dengan masukan teori dan hasli penelitian lapangan.

Teknik pengumpulan data dan informasi yang diperlukan untuk penelitian ini baik itu data primer mapun skunder dilakukan oleh peneliti dengan berikut ini;

Observasi Langsung

Teknik pengumpulan data melalui observasi langsung adalah cara pengambilan data dengan menggunakan mata tanpa ada pertolongan alat standar lain. Penulis mengumpulkan data dan informasi dengan cara meninjau dan melakukan pengamatan secara langsung ke lapangan terhadap suatu kegiatan yang sedang dilakukan atau berjalan, untuk memperoleh semua data yang dibutuhkan. Observasi dilakukan agar mengetahui secara langsung alur proses pembelian barang yang berada pada PT.XYZ di departemen purchasing order.

\section{Wawancara}

Wawancara merupakan proses memperoleh keterangan untuk tujuan penelitian dengan cara tanya jawab sambil bertatap muka. Wawancara secara langsung pada saat penelitian di departemen purchasing order dengan beberapa karyawan.

\section{Studi Pustaka}

Peneliti melaksanakan studi pustakaan untuk mendapatakan bahan tambahan dalam melengkapi kekurangan data yang didapatkan dari interview dan observasi.

\section{Literature Review}

\subsection{Import}

Impor adalah proses perdagangan barang yang memalui daerah pabean. Proses transaksi impor barang dari luar negeri ke dalam negeri melalui pabean Indonesia mesti memenuhi ketentuan peraturan perundang-undangan yang berlaku (Tandjung, 2011:379). Impor adalah proses memasukkan barang dari suatu negara (luar negeri) ke dalam wilayah pabean negara lain, Susilo (2008:101). Dalam pemahaman ini berarti proses import nterjadi antara dua negara. Dimana satu negara sebagai penyedia dan satu lagi sebagai pembeli. Menurut Purnawati, Impor adalah proses pembelian barang-barang dari luar negeri berdasarkan ketentuan atau peraturan pemerintah dimana pembayarannya memaikai valuta asing (Purnamawati, 2013:13).

Keputusan Direktur Jendral Bea dan Cukai Nomor KEP-07/BC/2003 tentang petunjuk pelaksanaan tatalaksana Kepabeanan adalah dasar hukum tatalaksana terkait dengan Impor. 
Selain itu Menteri Keuangan membuat keputusan Nomor 453/KMK.04/2002 tentang Tatalaksana Kepabeanan bidang impor. Di sana diatur terkait dengan komoditas yang bebas di wilayah pabean (dalam negeri), yang dibawa dari luar pabean (luar negeri) akan dikenakan bea masuk sesuai dengan tarifnya. Namun demikian, ada beberapa komoditas yang dibebaskan atau tidak dikenakan tarif. Hal ini menjadi dasar untuk seseorang atau badan usaha yang mana sudah mendapatkan ketetapan sebagai importir memiliki kewajiban untuk membayar bea masuk serta pajak seperti ketetapan pemerintah (Purba,1983:51).

\section{Persyaratan Impor}

Seseorang atau badan usaha yang akan melakukan import barang harus memilki syarat yang telah ditetapkan untuk import barang. Tentu barang importnya bukanlah barang yang terlarang oleh pemerintah. Adapun kelengkapan teknis untuk melakukan import barang meliputi API, NIK, NPWP dan perizinan lain yang sesuai dengan jenis barang impornya.

Dalam prakteknya, banyak perusahaan yang tidak memiliki ijin import menyewa perusahaan lain yang berijin import untuk membeli barang dari luar negeri. Untuk menghindari agar barang tidak di tahan di pabean, sebaiknya perijinan untuk import diperiksa dulu. Jangan sampai barang sudah sampai di pabean tetapi perijinan tidak lengkap. Hal ini akan mengakibatkan barang di tahan di pabean atau barang di kembalikan ke negara asal.

\section{Klasifikasi Barang Impor}

Peraturan Menteri Keuangan Republik Indonesia Nomor 110/PMK.010/2006 tanggal 15 November 2006 mengatur tentang klasifikasi barang yang di impor. Termasuk di dalamnya pembebanan tarif bea masuk atas barang impor. Terkait dengan adanya Asian Free Trade Area (AFTA) pemerintah mengeluarkan aturan untuk skema Common Effective Prefential Tariff (CEPT) for AFTA, yaitu peraturan Menteri Keuangan Republik Indonesia Nomor 125/PMK.010/2006 tanggal 15 November 2006.

Penomoran dan pengidentifikasian jenis barang untuk kebutuhan transaksi import maupun eksport di atur menggunakan HS (Harmonize System). Penomoran dan pengidentifkasian barang ini untuk membedakan barang yang satu dengan barang yang lainnya. Pada satu jenis barang masih dibedakan lagi menurut kualitas barangnya.

Penomoran dan pengidentifikasian berbagai jenis barang import ini adalah sangat berhubungan dengan pungutan tarif biaya bea masuk barang impor serta tarif ekspornya. Nomor ini adalah dasar yang dipakai Bea dan Cukai dalam memeriksa dokumen import yang dipakai. Kalau terjadi keragu raguan atau mencurigakan, petugas Bea \& Cukai secara selektif memeriksa fisik barang impor tersebut (Arbi, 2004:7).

\subsection{Purchase Order}

Purchase artinya pembelian, sedangkan order artinya pesanan. Secara harfiah berarti pesanan pembelian. Secara umum definisi purchase order menurut Hinkelman, Erward G adalah "pernyataan resmi yang diterbitkan oleh pembeli kepada penjual yang dalam pernyataan itu dilengkapi dengan segala syarat dan kondisi dari transaksi yang akan dilakukan". (Hinkelman, Edward G, 2002:165). Sedangkan Amir M.S mendefinisikan Purchase order adalah "surat pernyataan untuk persetujuan (akseptasi) dari importir atas penawaran eksportir dimana memiliki sifat mengikat secara hukum” (Amir MS, 2002:33).

Dengan demikian, purchase order (PO) ialah bukti tertulis dan sah yang menyatakan bahwa sesorang atau badan usaha betul-betul untuk melakukan transaksi jual-beli. Purchase $\operatorname{order}(\mathrm{PO})$ memuat informasi terkait jenis barang, jumlah, harga (satuan ataupun total), waktu dan lokasi pengiriman dan teknis pembayaran barang yang dipesan. Purchase order (PO) ialah 
dasar bagi penyedia untuk memproduksi barang berdasarkan pesanan customer. Apabila terjadi perselisihan terkait dengan purchase order (PO) dan penyedia tidak setuju dengan yang akan di transaksikan, maka penyedia akan membuat surat penolakan dan mengirimkan balek purchase order (PO) tersebut. Amir M.S menegaskan bahwa "penjual melaksanakan proses ekspor dengan berdasarkan pada purchase order (PO) untuk pedoman”, (Amir M.S, 2000:23).

\section{Proses Pesanan Pembelian/Purchase Order (PO)}

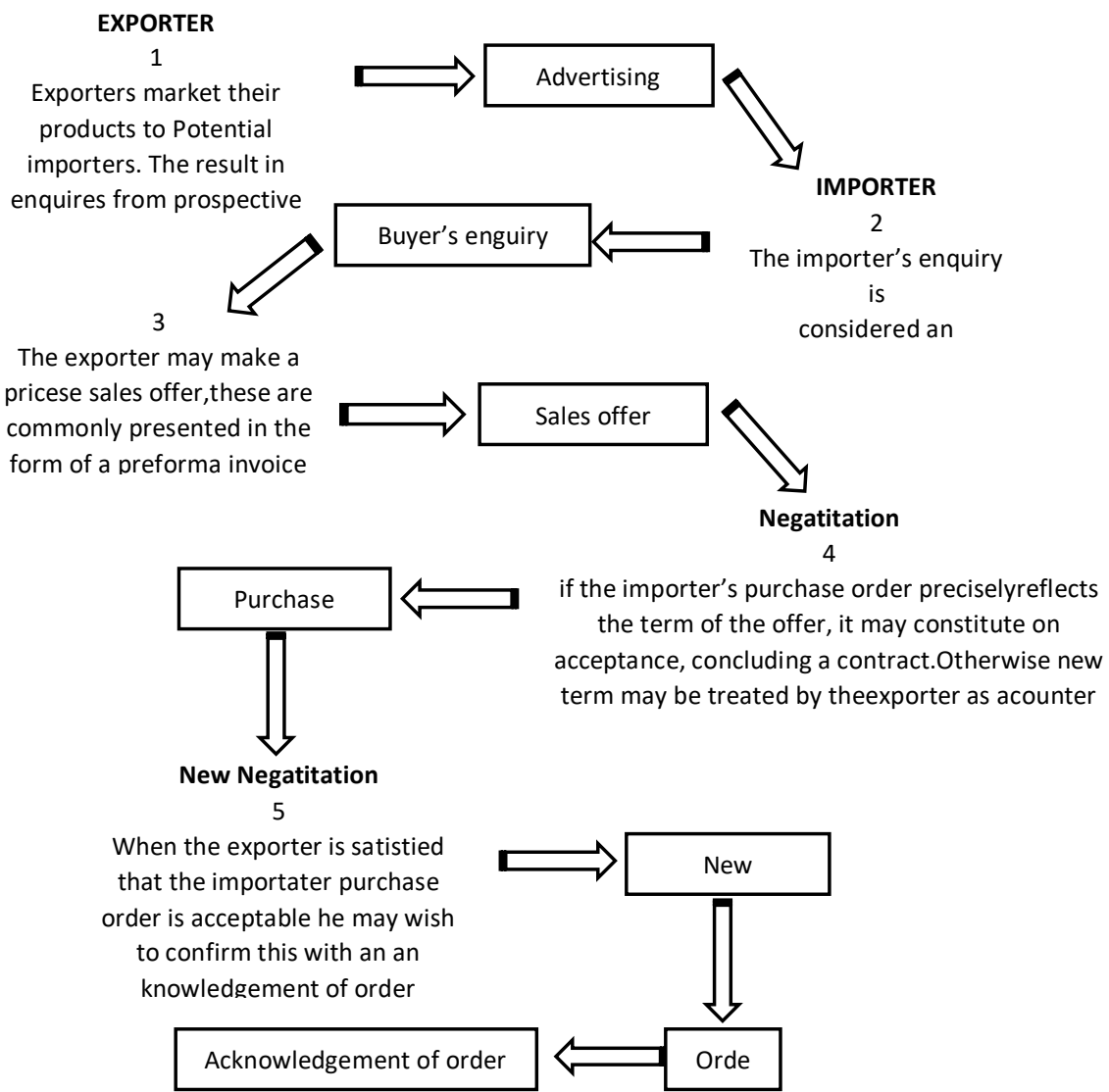

Sumber : ICC Guide to Export-Import Basics, dikutip dari Amir M.S 2001:15.

Figure1. PO process

Berdasarkan dengan gambar diatas, dapat dijelaskan prosesnya adalah berikut ini;

1. Penyedia barang akan mengiklankan atau mensosialisasikan produks barangnya kepada calon customer agar tertarik dan berminat untuk membeli produknya. Pembayaran bisa dilakukan dengan valuta asing (Amir M.S, 2001:14). Ada banyak cara untuk mempromosikan produknya seperti mengirimkan surat, datang langsung ke tempat, mengikuti pameran, iklan di media massa, mengundang calon customer atau dengan 
mendaftarkan produknya di Badan Pengembangan Ekspor Nasional (BPEN) atau National Agency for Export Development (NAFED) dan Indonesian Trade Promotion Centre (ITPC) di luar negeri.

2. Calon customer yang tertarik dengan produk yang ditawarkan oleh penyedia akan menghubungi dengan kirim surat permintaan penawaran harga. Dalam perdagangan internasional surat ini disebut dengan Letter of Inquiry for a Quotation atau Inquiry Letter. Isi surat tersebut menurut PPEI adalah "permintaan penawaran harga dengan memberitahukan mutu yang diinginkan, kuantitas yang dibeli, harga satuan dan harga total dalam valuta asing (US\$ Dollar dan lainnya), waktu pengiriman (shippment date) dan nama pelabuhan tujuannya" (PPEI, 2003:3).

3. Penyedia barang akan mengirim surat penawaran harga atau penawaran penjualan kepada calon customer. Surat penawaran ini akan dijadikan dalam dalam pembuatan formulir Proforma Invoice.

4. Calon customer akan mempelajari penawaran dari penyedia. Setelah calon pembeli menyetujui produk yang ditawarkan beserta harga dan persyaratan teknis transaksinya, selanjutnya akan diterbitkan purchase order (PO) kepada penyedia (penjual). Pesanan pembelian (PO) ini adalah penawaran untuk membeli yang dijadikan dasar bagi penjual. Setelah penjual menyetujui detai teknis PO tersebut maka penjual akan mengajukan kontrak pembelian. kontrak tidak akan terjadi kalau penjual tidak menyetuji. Detail syarat transaksi pembelian dalam penawaran biasanya dicetak dibalik surat pesanan. Kedua pihak baik itu penyedia (penjual) dan pembeli harus teliti agar klausul yang dilampirkan sesuai dengan kondisi yang disetujui oleh kedua pihak. Kalaupun ada, persyaratan teknis (klausul) yang berbeda dengan persyaratan yang diterapkan oleh penjual sebaiknya dibicarakan kedua pihak sebelum kontrak tersebut ditanda tangani. "Jika isi purchase order (PO) yang dikirim oleh pembeli mencerminkan syarat-syarat yang telah dibuat oleh penjual, maka sebuah proposal baru tentang pemesanan barang akan dilakukan." (Shippey, Karla G, 2001:155)

\section{Discussion}

\subsection{Proses PO (Purchase Order)}

Dalam proses transaksi jual dan beli suatu produks mesti memuaskan kedua pihak, baik itu penjual ataupun pembeli. Supaya tercapai kesepakatan bersama dalam proses pengadaan atau pembelian barang diperlukan ketelitian dan koordinasi kedua pihak. Ada juga kesepakatan tidak tercapai dan transaksi batal. Oleh karena itu dalam penelitain ini memfokuskan pada hal hal supaya yang tercapai kesepakatan transaksi bisnis khususnya analisis terkait dengan penerbitan purchase order (PO).

Pihak pembeli akan meneliti detail jenis dan kualitas produks (barang) sebelum menerbitkan Purchase order (PO) dan dikirimk kepada penjual (penyedia). Detail jenis dan kualitas barang dapat diketahui dari iklan, penawaran, pameran atau katalog yang diberikan. Purchase order (PO) yang dikirimkan kepada penyedia barang tentu akan berisi spesifikasi barang yang dibutuhkan. Jika penjual setuju dengan detail teknis barang yang di purchase order (PO) maka penyedia akan memproduksi barang sesuai dengan purchase order (PO) dengan terlebih dahulu mengirim Performa Invoice kepada pembeli. Performa Invoice adalah sebagai bentuk tanggapan (respon) bahwa penyedia sudah menerima dan setuju dengan purchase order (PO) serta akan menjual barang sesuai yang dipesan. Pembeli akan 
mengajukan teknis packing, ekspedisi barang, waktu dan lokasi pengiriman barang. Teknis pembayaran dan persyaratan penyerahan barang tentu sudah disepakati dahulu oleh kedua pihak.

Terkait dengan ekspedisi barang, perlu dimasukkan asuransi agar tidak terjadi kerusakan barang. Penting untuk membicarakan pihak mana yang harus menanggung beban biaya asuransi barang termasuk memakai FOB destination atau FOB shipping point. Pemilihan ini berdampak pada siapa yang akan menanggung ekspedisi dan asuransinya, apakah itu penjual atau pembeli.

Perlu juga dibicarakan terkait dengan syarat hukum dua negara yang berbeda. Perlu dinegosiasikan, apakah menggunakan hukum negera ekportir atau importir yang diapaki. Jika tidak bisa bersepakat maka kemungkinan besar akan mengabaikan masalah tersebut. Biasanya yang terjadi adalah menggunakan hukum yang berlaku di negara importir (pembeli). Negara eksportir biasanya prosedur hukumnya lebih sederhana dan lebih terjamin penegakan hukumnya

\section{Hambatan-hambatan dalam proses PO (Purchase Order)}

Secara umum masalah yang dihadapi dalam proses purchase order (PO) adalah waktu kirim, teknis pembayaran, teknis dan lokasi penyerahan barang, harga satuan barang dan jumlah harga total. Yang paling sering terjadi adalah teknis waktu dna tempat pengiriman barang. Ini akan sering terjadi karena di bagian purchasing (pembielian) tidak mengisi bagian atau kolom "condition". Apabila ini terjadi maka proses transaksi pembelian barang atau purchase order akan terhenti atau gagal.

\section{Tawaran Solusi dan masukan}

Hambatan-hambatan dari proses Purchase Order diatas dapat mengakibatkan keracunan dalam menyelesaikan pekerjaan di setiap divisi. Dimana akibatnya keterlambatan yang terjadi setiap divisi dapat ditolelir. Hal ini menimbulkan kesulitan dalam pembuatan rencana operasional perusahaan. Sehingga disarankan agar setiap penulisan uraian dalam PO (Purchase Order) ditulis dengan jelas serta detail. Hal ini diusulkan agar jelas setiap unsur dalam PO (Purchase Order) agar dapat terhindar dari kesalahpahaman dengan kesepakatan yang tercantum dalam PO (Purchase Order).

Pembuatan DML (daily market list) adalah bagian dari tugas purchasing yang secara rutin dilakukan untuk ketersediaan barang yang dibutuhkan. Pembuatan PO adalah tugas utama bagian purchasing untuk memenuhi segala jenis barang pesanan yang dibutuhkan semua bagian untuk kelancaran operasional perusahaan.

Khusus untuk menangani order tambahan dimana proses DML (daily market list) sudah berjalan, departemen terkait tetap harus tetap mengisi form DML untuk melakukan pemesanan seperti prosedur. Bagian purchasing perlu menyediakan form DML untuk persiapan pengadaan tambahan. DML tambahan tersebut biar diproses sendiri prosedurnya oleh departemen terkait dan bagian purchasing tinggal melakukan order.

Penyimpanan arsip sangat membantu pekerjaan bagian purchasing untuk mempertanggungjawabankan tugas dan kewajiban kepada atasan. Selain itu, arsip ini sangat berguna untuk acuan proses pembelian berikutnya. Untuk meningkatkan kualitas proses Pengadaan Barang perlu memiliki prinsip prinsip dasar pengadaan barang yaitu efisien, efektif, transparan, terbuka, harga bersaing, Adil/tidak diskriminatif, akuntabel, 


\section{Conclusions And Suggestions}

Berdasarkan hasil pengamatan di lapangan dan simulasi analisa yang telah diuraikan pada bab sebelumnya, maka dapat ditarik suatu kesimpulan yang berupa ringkasan dan penulis berupaya mengemukakan saran yang mungkin berguna.

\subsection{Conclusions}

Pembelian (purchasing) adalah proses yang sangat oenting dalam suatu perusahaan dan bagian dari fungsi dasar perusahaan. Sangat penting karena siklus bisnis perusahaan tidak dapat terjadi kalau proses purchasing (pembelian) tidak ada. Pembelian adalah awal dari siklus bisnis untuk meningkatkan nilai tambah suatu barang oleh sebuah perusahaan

Secara umum hambatan yang sering terjadi dalam dalam purchase order (PO) adalah waktu dan tempat pengiriman, teknis dan jenis pembayaran, syarat teknis penyerahan barang, harga satuan barang dan harga total keseluruhan. Perlu diperhatikan lagi terkait dengan teknis waktu dan tempat penyerahan barang. Biasanya ini terjadi karena di purchase order tidak mengisi bagian (kolom) "condition". Ini menimbukan kerancuan dalam pelaksanaan teknis pekerjaan dan proses purchase order akan terhenti atau gagal. Sehingga disarankan agar setiap penulisan uraian dalam PO (Purchase Order) ditulis dengan jelas dan detail. Hal ini diusulkan supaya jelas setiap unsur dalam PO (Purchase Order) agar dapat terhindar dari kesalahpahaman dengan kesepakatan yang tercantum dalam PO (Purchase Order).

Pembuatan DML (daily market list) mutlak perlu dilakukan untuk menjaga ketersediaan ketersediaan barang yang dibutuhkan. Khusus untuk order tambahan dimana proses DML (daily market list) sudah berjalan, departemen terkait tetap harus tetap mengisi form DML untuk melakukan pemesanan seperti prosedur.

Penyimpanan arsip sangat membantu pekerjaan bagian purchasing untuk mempertanggungjawabankan tugas dan kewajiban kepada atasan. Selain itu, arsip ini sangat bermanfaat sebagai acuan proses pembelian berikutnya

\subsection{Suggestions}

Department purchasing (pembelian) memiliki peranan dan fungsi yang sangat penting dan bukanlah pekerjaan yang mudah. Diperlukan kelincahan, ketepatan, keuletan dan juga keterampilan untuk mengolah dan menganalisa barang dan atau jasa yang akan dipakai. Disarankan, hendaknya perusahaan lebih meningkatkan dalam hal menyesuaikan jadwal PO (Purchase Order) dengan kemampuan produksinya serta menjaga hubungan baik dengan instansi yang terlibat dalam proses ekspor dan menjaga kepercayaan dari seller luar negeri sehingga terpeliharanya hubungan kerjasama yang baik.

Perlu disiapkan DML (daily market list) tambahan untuk berjag jaga kalau ada order tambahan dimana proses DML (daily market list) sudah berjalan.

Penyimpanan harus dilakukan dengan rapi dan teliti untuk mempertanggungjawabankan tugas kepada atasan dan untuk menjadi acuan proses pembelian berikutnya

\section{References}

[1]. Amir, MS. 2000. Seluk Beluk dan Teknik Perdagangan Luar NegeriI. PPM. Jakarta

[2]. Amir, M.S. 2001. Ekspor Impor Teori \& Penerapannya. PPM. Jakarta.

[3]. Amir M.S, 2002, Kontrak Dagang Ekspor, Penerbit PPM, Jakarta.

[4]. Arbi, Syarif, H.M., Drs. M.M., 2004, Petunjuk Praktis Perdagangan Luar Negeri seri impor, Yogyakarta : BPFE-YOGYAKARTA 
[5]. Cahyo Susilo, Bayu. 2008. Pengaruh Kurs Dollar, Inflasi Dan Suku Bunga Terhadap Harga Sahan Di BEI (Study kasus Pada Perusahaan Manufaktur Go Public di BEI). Skripsi. Surakarta: FE UMS.

[6]. Hady, Hamdy, Teori dan Kebijakan Perdagangan Internasional, Ghalia Indonesia, Jakarta, 2004.

[7]. Hinkelman, Erward G, 2002, Pembayaran Bisnis Internasional, Penerbit PPM, edisi I seri Bisnis Internasional no. 12

[8]. Ineke Febriana H, 2009, Analisa Proses PO (Purchase Order) pada PT. Kusumahadi Santosa di Karanganyar.

[9]. Radiks Purba, 1983, Pengetahuan Perdagangan Luar Negeri Indonesia,. Pustaka Dian, Jakarta.

[10]. Pendidikan dan Pelatihan Ekspor Indonesia (PPEI). 2010. Daftar 10 Produk Utama Indonesia. http://www.ppei.kemendag.go.id. [26 Februari 2014]

[11]. Purnamawati, A. dan S. Fatmawati. 2013. Dasar-dasar Ekspor Impor (Teori, Praktik, dan Prosedur). Upp Stim Ykpn, Yogyakarta.

[12]. Shippey, Karla C. Menyusun Kontrak Bisnis Internasional-Panduan Menyusun Draf Kontrak Bisnis Internasional. Jakarta: PPM, 2001.

[13]. Tandjung, Marolop (2011). “Aspek dan Prosedur Ekspor Impor”. Jakarta. Salemba Empat.

[14]. Direktur Jendral Bea dan Cukai Nomor KEP-07/BC/2003. Tentang petunjuk pelaksanaan Tatalaksana Kepabeanan di bidang impor.

[15]. Keputusan Menteri Keuangan Nomor 453/KMK.04/2002 tentang Tatalaksana Kepabeanan di bidang impor.

[16]. Peraturan Menteri Keuangan Republik Indonesia Nomor 125/PMK.010/2006 tanggal 15 November 2006. 